\title{
Are Employers Changing Their Behavior Toward Older Workers? An Analysis of Employers' Surveys 2000-2009
}

\section{Wieteke S. Conen MSc, Kène Henkens PhD \& Joop J. Schippers PhD}

To cite this article: Wieteke S. Conen MSc, Kène Henkens PhD \& Joop J. Schippers PhD (2011) Are Employers Changing Their Behavior Toward Older Workers? An Analysis of Employers' Surveys 2000-2009, Journal of Aging \& Social Policy, 23:2, 141-158, DOI: 10.1080/08959420.2011.551612

To link to this article: https://doi.org/10.1080/08959420.2011.551612

Submit your article to this journal $\sqsubset$

Џ Article views: 866

Q View related articles 두

4 Citing articles: 37 View citing articles 준 


\title{
Are Employers Changing Their Behavior Toward Older Workers? An Analysis of Employers' Surveys 2000-2009
}

\author{
WIETEKE S. CONEN, MSc \\ Researcher, Netherlands Interdisciplinary Demographic Institute, \\ The Hague, The Netherlands, and \\ Faculty of Law, Economics, and Governance, Utrecht University, The Netherlands \\ KÈNE HENKENS, PhD \\ Professor, Department of Sociology, Tilburg University, The Netherlands, and \\ Netherlands Interdisciplinary Demographic Institute, The Hague, The Netherlands \\ JOOP J. SCHIPPERS, PhD \\ Professor, Faculty of Law, Economics, and Governance, \\ Utrecht University, The Netherlands \\ This article addresses possible changes in Dutch employers' behav- \\ ior regarding the recruitment and retention of older workers \\ during the last decade. The authors analyze surveys administered \\ to Dutch employers in 2000, 2002, 2005, 2008, and 2009. The \\ results show that efforts to recruit older workers are changing, \\ congruous with the economic climate, while retention behavior \\ shows a clear and rather gradual time effect. The authors conclude \\ that the position of older workers has improved between 2000 and \\ 2008 and has done so in comparison with other underrepresented \\ groups in the labor market. During the recession, recruitment of \\ older workers declined substantially, while efforts to retain older \\ workers are in both absolute and relative terms higher than in \\ 2000. With respect to organizational policies, the authors con- \\ clude that throughout the period under observation these policies \\ are dominated by measures that "spare" older workers.
}

Received July 15, 2009; revised November 15, 2009; accepted February 14, 2010.

This research is funded by the EU Seventh Framework Programme (FP7/2007-2013) under grant FP7-216289 (ASPA).

Address correspondence to Wieteke S. Conen, Netherlands Interdisciplinary Demographic Institute, P.O. Box 11650, NL-2502 AR The Hague, The Netherlands. E-mail: conen@nidi.nl 
KEYWORDS aging, employers' behavior, older workers, organizational policies, recruitment, retention

\section{INTRODUCTION}

Raising the participation levels of older workers is one of the key objectives of policy makers in most Western countries (OECD, 2001). However, macroeconomic targets for increasing participation and increasing older people's working lives are unlikely to be met without employers' active support. There is still limited insight into how employers are behaving toward older workers, whether this behavior is subject to change, and whether it is in line with those macro-level policies aimed at extending the working life (European Commission, 2004, 2005). Earlier research among employers, carried out in the United States and several European countries, shows that there is often a lack of corporate focus on older employees; this is reflected in an absence of programs to retain and retrain them (Barth, McNaught, \& Rizzi, 1993; Chiu, Chan, Snape, \& Redman, 2001; Guillemard, Taylor, \& Walker, 1996; Henkens, 2005; Taylor \& Walker, 1998; Van Dalen, Henkens, \& Schippers, 2009, 2010). Furthermore, micro- and meso-level actors, including employers and employees themselves, seem to hold a double standard toward increasing the number of older workers and postponing retirement; while agreeing that working longer may well become necessary in the future, workers and employers still do not think it will apply to them individually (Van Dalen et al., 2009).

This situation raises several questions. Are employers responsive to all kinds of "management by speech" from public officials and becoming more aware of the challenges ahead? And-an even more interesting questiondo they behave accordingly? After all, Vickerstaff, Cox, and Keen (2003) have concluded earlier that any significant change in retirement behavior will come primarily from policy modifications initiated and undertaken by employers. This paper examines the behavior of employers in retaining and recruiting older workers and will address three main questions:

- Viewed over the last decade, do employers' retention and recruitment behaviors toward older workers show any major changes?

- Compared to other underrepresented groups in the labor market, has the relative position of older workers in the "job queue" been changing over the last decade? The "job queue" (Thurow, 1975) refers to the idea of employers - who are in the process of recruitment and selectionranking potential employees and placing them in a fictitious order of preference.

- Have organizational policies regarding older workers been changing over the last decade? 
To answer these questions, we analyze the results of independent surveys among Dutch employers carried out in 2000, 2002, 2005, 2008, and 2009. In this paper we make a distinction between two elements of a time effect: (1) a trend effect or structural effect and (2) a business-cycle effect. The first effect refers to a trend, or structural change, in the time period under observation. This trend effect indicates a fundamental change from the point of reference in a positive or negative direction. The second effect refers to an effect caused by changes in the business cycle. In our case it means, for example, that when the demand for workers changes, the demand for older workers changes as well.

\section{POLICY CONTEXT}

Reversing the Exit Culture: Blocking Pathways Out of the Labor Market

Since the 1980s, the mobility of older workers has been dominated by exit mobility in the Netherlands. The three most important pathways out of the labor market have been early retirement, disability, and unemployment. From the 1990s onward, the Dutch government has concentrated on reversing the exit culture by blocking those exit routes. The first route the government attempted to close was the disability route, frequently used by employers to lay off workers. The measures taken have resulted in a strong decline in the inflow of workers into disability arrangements.

But the three pathways out of the labor market are not independent: closing one road results in more use of the other roads (Van Imhoff \& Henkens, 1998). That is why in recent years the government, in its attempts to increase older workers' labor force participation, has also directed its attention to the other two exit routes: early retirement and unemployment schemes. Voluntary early retirement schemes, based on pay-as-you-go funding, have been transformed into actuarially neutral pre-pension schemes on a capital funded basis, and early retirement was further restricted by a new law in 2006. Both adjustments make if financially more attractive for older workers to prolong working life. Blocking unemployment schemes was addressed by reducing the maximum period of unemployment benefit entitlement and tightening rules on eligibility criteria.

Currently, the Dutch government is considering additional measures to reverse the exit culture. In 2009, plans were launched to raise the public pension age from 65 to 67 in about 2025. The way this increase will be realized (gradually, stepwise, or with a "big bang") is still under discussion.

Age Discrimination Legislation

Age discrimination is one of the forces behind the phenomenon of the Dutch "early exit culture." Koppes, De Vroome, Mol, Janssen, \& Van den 
Bossche (2009) show that in the Netherlands age discrimination is perceived to be substantial: the self-reported rate of age discrimination in the category of older workers ( 55 to 64 years) is 20\%. As in other European countries, age discrimination laws in the Netherlands are of fairly recent date. In 2004, the government introduced specific regulation to combat age discrimination by enacting the Age Discrimination in Employment Act. This act prohibits discrimination based on age or behaviors that are the result of the difference in age in the field of labor. The act applies to filling vacancies, employment finding, and the beginning or ending of labor relations. Someone who presumes to be a victim of age discrimination can request the Dutch Equal Treatment Commission to start an inquiry. The Dutch Equal Treatment Commission reports that about one-quarter to one-third of discrimination complaints refer to cases of age discrimination (Equal Treatment Commission, 2007).

\section{Trends in Participation and Unemployment Rates}

Looking at participation rates of adults between ages 55 and 64 over the years (see Figure 1), policy makers might conclude that these rates gradually move to the "right" direction. In 2001, the European Council defined a target for raising the average labor force participation of adults between ages 55 and 64 to $50 \%$ by 2010 (European Council, 2001). Although the participation rate of Dutch workers aged 55 to 64 has increased substantially in recent years (47\% in 2009), it is still below the target set.

Over the last decade, there have been both expansion and contraction in the Dutch labor market, as reflected in fluctuations of the overall unemployment rate (see Figure 2). The period 2000 to 2005 was marked by

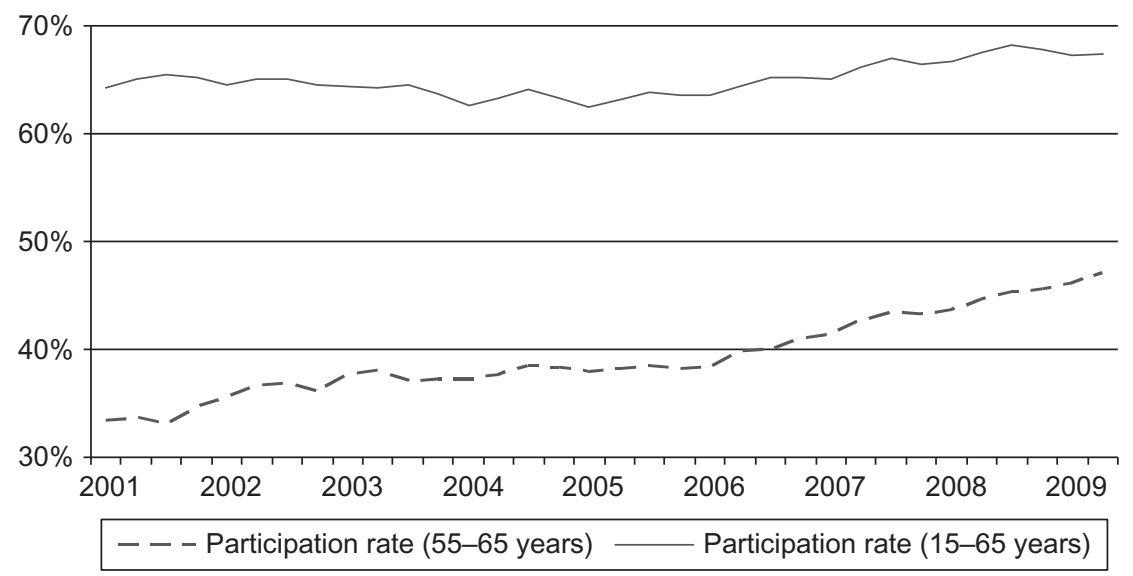

FIGURE 1 Labor force participation rate, period 2001-2009.

Source: Statistics Netherlands, 2009. 


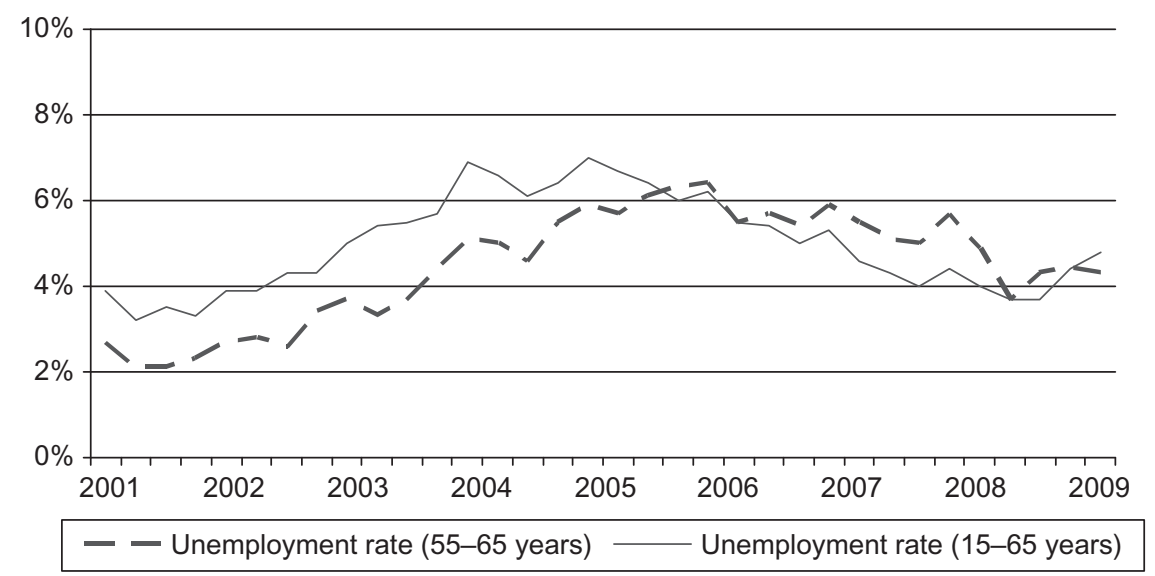

FIGURE 2 Unemployment rate, period 2001-2009.

Source: Statistics Netherlands, 2009.

growing unemployment, while 2005 to 2008 was a period of sharp contraction. In 2008, the unemployment rate was at a similar level as in 2000. Since the beginning of the economic downturn in the second quarter of 2008, unemployment rates have been rising again.

Particularly when economic prospects are weak, older workers find themselves in a vulnerable position. Note in Figure 2 that the unemployment rate of older workers remains relatively high for several years after the "general" peak in 2005. This seems to underscore the idea that when there are enough "other fish in the pond" older workers are among the last in the "job queue." Thus, their position still remains precarious during the period after an economic downturn, when younger workers already benefit from job growth.

The time frame of 2000 to 2009 thus provides us with the opportunity to analyze whether employers' behavior toward older workers is affected by labor market fluctuations and corresponding perceived labor shortages or whether there is a more constant time effect.

\section{THEORETICAL BACKGROUND}

\section{Rational Organizations and Aging}

A basic tenet of organizational theory is that organizations are goal-oriented systems that strive for profit maximization, continuity, and a healthy market position (Kalleberg, Knoke, Marsden, \& Speath, 1996). These objectives could be described as basic organizational goals. Employers' behavior toward older workers is assumed to be dependent on older workers' contributions in achieving these goals, given the restriction that organizations face. One organizational characteristic that may influence employers' behavior 
toward older workers is the skill level required to do a job properly. Assuming that highly skilled and experienced workers are better equipped to acquire new skills and prevent their knowledge from becoming obsolete, we hypothesize that organizations that rely more heavily on highly skilled workers are more likely to recruit and retain older employees than organizations relying more on low-skilled workers (buman-capital bypothesis).

The decision to retain or recruit older workers is made within the context of the broader organization. This is not a static context, but one that is dynamically changing. Macro-level developments, such as economic changes, influence the choices made by managers. When organizations are shedding jobs as a result of an economic downturn or a declining demand for output, managers will be more pressured to implement cost-savings measures than in a favorable economic climate. We predict that perceived labor shortages will increase the likelihood of recruitment or retention of older workers (business-cycle bypothesis).

\section{Institutional Isomorphism}

The larger cultural and political contexts in which employers operate, or more generally the "institutional surroundings," may play an important role in how employers behave toward older workers. In the theory of DiMaggio and Powell (1983), the notion of "institutional isomorphism" (literally: taking on the same form or structure as another organism) identifies three mechanisms through which institutional change occurs: coercive, mimetic, and normative institutional isomorphism. Coercive institutional isomorphism stems from political influence and concerns the pressure exerted, either formally or informally, by other organizations, society's expectations, or by the government. Mimetic isomorphism results from standard responses to uncertainty and concerns the imitation of practices of other organizations. Normative isomorphism results from managers going to the same university or school, reading the same journals, going to the same conferences, and picking up the same ideas about what an organization should be like; it concerns the professionalization of the organization.

As stated before, during the last decade policy makers have preached the necessity to reverse the exit culture. Besides the more formal pressure we discussed in the political context, management by speech may also be interpreted as the kind of pressure that results in coercive institutional isomorphism. For example, in 2001, the Dutch Government installed the "Taskforce on Older People and Employment" and, in 2005, the coordinating group "Grey Works." These initiatives relied to a large extent on management by speech; by giving lectures, calling work committees, advertising, and informing the press, they aimed at improving the employment prospects of older adults. A growing awareness of the aging process may have changed the behavior of employers in a positive direction, so that 
employers are gradually more likely to recruit and retain older employees within their organizations. The persistence of a time effect, even when controlled for business-cycle fluctuations, indicates a trend or structural effect. We hypothesize that, corrected for business-cycle effects over the period 2000 through 2009, employers have increasingly recruited and retained older employees (trend-effect bypothesis).

\section{METHODS}

\section{Data}

The research questions will be answered using data from comparative surveys carried out independently among Dutch employers in 2000, 2002, 2005, 2008, and 2009. The questionnaires used in each of the 5 years contained similar questions on recruitment and retention measures, personnel policies, and features of the organization. The names and addresses of the privatesector organizations were taken from samples drawn from the trade register of the chamber of commerce. To include public-sector organizations, questionnaires were sent to organizations active in public administration and in the health and welfare sector. All questionnaires were sent by postal mail.

The total number of completed questionnaires amounts to 4,386, of which 1,016 are from 2000, 1,054 from 2002, 597 from 2005, 674 from 2008, and 1,045 from 2009. The total response rate ranged from 15\% to 36\% (see Table 1), which is lower than the average response rate for individual surveys but in line with the rate generally found in corporate surveys. In Europe and the United States, response rates have been found to be $20 \%$ to $30 \%$ at most (see Brewster, Hegewisch, Mayne, \& Tregaskis, 1994; Kalleberg et al., 1996). For the purpose of this study, we used 2,833 questionnaires completed by board members/managing directors (29\%), owners (17\%), plant managers (7\%), and the heads of human resources departments (48\%). In Table 1, these respondents are referred to as "executives." All relevant data have been merged to obtain a pooled cross-section data set.

Table 1 shows that data collection covered all sectors of the Dutch economy. Comparison with information from Statistics Netherlands revealed that the data are not representative for the sector distribution in each year. This has been corrected by taking "sector" into account in the regression analyses and by attaching weights according to the population of organizations from Statistics Netherlands in the presentation of cross tabulations.

\section{Variables and Analyses}

A pooled cross-section data set was used for the analyses. To answer the first research question, we performed multivariate logistic regression to analyze employers' behavior toward older workers over the last decade. 
TABLE 1 Descriptive Characteristics of Samples Used

\begin{tabular}{|c|c|c|c|c|c|}
\hline Year & $N$ & $\begin{array}{l}\text { Response } \\
\text { rate }\end{array}$ & $\begin{array}{c}N \\
\text { (Executives) }\end{array}$ & $\begin{array}{l}\text { Sector distribution } \\
\text { in the sample }\end{array}$ & $\begin{array}{l}\text { Sector distribution } \\
\text { according to } \\
\text { Statistics Netherlands }\end{array}$ \\
\hline 2000 & 1,016 & $36 \%$ & 694 & $\begin{array}{l}\text { Industry and } \\
\text { construction }(29 \%) \\
\text { Service sector }(30 \%) \\
\text { Public sector }(41 \%)\end{array}$ & $\begin{array}{l}\text { Industry and } \\
\quad \text { construction }(19 \%) \\
\text { Service sector }(64 \%) \\
\text { Public sector }(17 \%)\end{array}$ \\
\hline 2002 & 1,054 & $31 \%$ & 697 & $\begin{array}{l}\text { Industry and } \\
\text { construction }(21 \%) \\
\text { Service sector }(24 \%) \\
\text { Public sector }(55 \%)\end{array}$ & $\begin{array}{l}\text { Industry and } \\
\text { construction (20\%) } \\
\text { Service sector }(63 \%) \\
\text { Public sector }(17 \%)\end{array}$ \\
\hline 2005 & 597 & $15 \%$ & 282 & $\begin{array}{l}\text { Industry and } \\
\text { construction }(23 \%) \\
\text { Service sector }(44 \%) \\
\text { Public sector }(33 \%)\end{array}$ & $\begin{array}{l}\text { Industry and } \\
\quad \text { construction }(19 \%) \\
\text { Service sector }(62 \%) \\
\text { Public sector }(19 \%)\end{array}$ \\
\hline 2008 & 674 & $17 \%$ & 367 & $\begin{array}{l}\text { Industry and } \\
\text { construction (30\%) } \\
\text { Service sector (33\%) } \\
\text { Public sector }(37 \%)\end{array}$ & $\begin{array}{l}\text { Industry and } \\
\quad \text { construction }(21 \%) \\
\text { Service sector }(63 \%) \\
\text { Public sector }(17 \%)\end{array}$ \\
\hline 2009 & 1,045 & $23 \%$ & 793 & $\begin{array}{l}\text { Industry and } \\
\text { construction }(33 \%) \\
\text { Service sector }(31 \%) \\
\text { Public sector }(36 \%)\end{array}$ & $\begin{array}{l}\text { Industry and } \\
\quad \text { construction }(21 \%) \\
\text { Service sector }(63 \%) \\
\text { Public sector }(17 \%)\end{array}$ \\
\hline
\end{tabular}

The dependent variable on retention behavior was operationalized by asking respondents whether they encouraged workers to continue working until they reach age 65 ("1" currently applied, "0" not applied). Recruitment behavior was operationalized by asking whether employers recruited older workers ("1" currently applied, "0" not applied). "Older workers" were defined in the questionnaire as "workers ages 50 years and older." Descriptive statistics of the variables used in the analyses are presented in Table 2.

In our models, the trend effect and business-cycle effect are separated in order to examine whether a possible time effect is either cyclical or structural in nature. For the trend effect, we constructed year dummies. To account for business-cycle effects, we included two variables: size changes and experienced labor shortages. The organizations' demand for labor is related to growth or contraction of the organization. This is captured in the question of whether the number of employees changed in the last few years ("1" Yes, it grew; "2" No, it stayed (more or less) the same; "3" Yes, it contracted). Whether this demand for labor is being met is influenced by the external labor market. The degree of personnel shortages experienced was measured by asking respondents to what extent they encountered problems finding staff ("1" with a relatively large number of positions, "2" with some positions, "3" hardly ever). 
TABLE 2 Descriptive Statistics $(N=2,833)$

\begin{tabular}{|c|c|c|c|c|}
\hline & Mean & $S D$ & Min & Max \\
\hline \multicolumn{5}{|l|}{ Dependent variables } \\
\hline \multicolumn{5}{|l|}{ Recruitment } \\
\hline Recruitment older workers $(0=$ no, $1=$ yes $)$ & 0.18 & 0.38 & 0 & 1 \\
\hline \multicolumn{5}{|l|}{ Retention } \\
\hline Retention older workers $(0=$ no, $1=$ yes $)$ & 0.18 & 0.39 & 0 & 1 \\
\hline \multicolumn{5}{|l|}{ Independent variables } \\
\hline \multicolumn{5}{|l|}{ Trend effect } \\
\hline \multicolumn{5}{|l|}{ Year $(2000=$ reference category $)$} \\
\hline 2002 & 0.25 & 0.43 & 0 & 1 \\
\hline 2005 & 0.10 & 0.30 & 0 & 1 \\
\hline 2008 & 0.13 & 0.34 & 0 & 1 \\
\hline 2009 & 0.28 & 0.45 & 0 & 1 \\
\hline \multicolumn{5}{|l|}{ Business-cycle effect } \\
\hline \multicolumn{5}{|l|}{ Size change $($ contraction $=$ reference category $)$} \\
\hline Constant & 0.34 & 0.47 & 0 & 1 \\
\hline Growth & 0.50 & 0.50 & 0 & 1 \\
\hline \multicolumn{5}{|l|}{$\begin{array}{l}\text { Experienced shortages (no shortages }=\text { reference } \\
\text { category) }\end{array}$} \\
\hline With some vacancies & 0.49 & 0.50 & 0 & 1 \\
\hline With relatively many vacancies & 0.22 & 0.42 & 0 & 1 \\
\hline \multicolumn{5}{|l|}{ Human capital hypothesis } \\
\hline \multicolumn{5}{|l|}{$\begin{array}{l}\text { Educational level (predominantly low } \\
\text { skilled = reference category) }\end{array}$} \\
\hline Predominantly medium-skilled & 0.31 & 0.39 & 0 & 1 \\
\hline Predominantly high-skilled & 0.14 & 0.29 & 0 & 1 \\
\hline Equally distributed & 0.15 & 0.30 & 0 & 1 \\
\hline \multicolumn{5}{|l|}{ Control variables } \\
\hline Size of the organization (logarithm) & 4.68 & 1.40 & 0.69 & 11.66 \\
\hline \multicolumn{5}{|l|}{$\begin{array}{l}\text { Sector of industry (public sector }=\text { reference } \\
\text { category) }\end{array}$} \\
\hline Industry and construction & 0.31 & 0.46 & 0 & 1 \\
\hline Services & 0.32 & 0.47 & 0 & 1 \\
\hline \multicolumn{5}{|l|}{$\begin{array}{l}\text { Share of workers older than } 50 \text { years } \\
\text { (none }=\text { reference category) }\end{array}$} \\
\hline $1 \%-9 \%$ of the workers older than 50 & 0.18 & 0.39 & 0 & 1 \\
\hline $10 \%-19 \%$ of the workers older than 50 & 0.28 & 0.45 & 0 & 1 \\
\hline $20 \%-29 \%$ of the workers older than 50 & 0.26 & 0.44 & 0 & 1 \\
\hline $30 \%$ or more of the workers older than 50 & 0.23 & 0.42 & 0 & 1 \\
\hline Share female staff & 36.68 & 28.05 & 0 & 100 \\
\hline Age of respondent & 45.54 & 9.02 & 19 & 83 \\
\hline Gender of respondent & 0.70 & 0.46 & 0 & 1 \\
\hline
\end{tabular}

To test the human-capital hypothesis, we included a breakdown of the workforce by level of education (" 1 " predominantly low-skilled, "2" predominantly medium-skilled, "3" predominantly high-skilled, "4" equally distributed).

In addition, employment prospects of older workers may differ according to organizational settings (e.g., size, sector, and gender or age composition) and personal attributes of the employers or managers (Henkens, 2005). 
The control variables on organizational characteristics and characteristics of the respondent were assessed using 6 variables. To control for sector differences, respondents were given a list of industrial sectors defined by Eurostat (1990) and were asked to indicate the sector in which their own organization operated. We categorized the sectors into "industry and construction," "services," and "public sector." Furthermore, respondents were asked for the number of male, female, and total number of employees; the share of female employees and the size of the organization were derived from these questions. Fourth, the share of older workers aged "50 and older" was categorized in 2000 ("1" no older workers, "2" 1\% to 9\%, "3" 10\% to 19\%, "4" $20 \%$ to $29 \%$, "5" 30\% or more of workers over 50). For the years 2002, 2005, 2008, and 2009, when the "share of older workers aged 50 and older" was a continuous variable, the number was recoded to the same categories. This variable has been transformed into a series of dummies. To account for possible differences in personal employers' attributes, we included age and sex as control variables in the analysis (" 1 " male, "0" female).

To answer the second research question, we examined the relative position in the job queue. This position was derived from the behavior toward older workers as compared to other underrepresented groups in the Dutch labor market. Behavior toward older workers was derived from the question of whether the organization encouraged workers to continue working until they reach age 65 and whether employers recruited older workers ("1" currently applied, "0" not applied). The behavior toward other eminent underrepresented groups is measured by asking whether employers recruited women, non-natives, and disabled or partially disabled people ("1" currently applied, "0" not applied).

To answer the third research question of whether organizational policies regarding older workers have been changing over the last decade, we measured policies aimed specifically at older workers. The questionnaires included several policy measures regarding older workers, including measures aimed at adjusting tasks and capabilities, enhancing work-leisure trade-off, and measures aimed at over-fatigue prevention ("1" currently applied, "0" not applied). The list of policy measures was based on an earlier study into age-conscious personnel policies in organizations (SZW, 1991).

\section{RESULTS}

\section{Retention and Recruitment Behaviors}

Table 3 presents the results of multivariate logistic regression analyses to explain employers' retention and recruitment behaviors toward older workers over the last decade. The odds ratio represents the ratio of the probability that employers retain or recruit older workers to the probability that they will not. The depicted odds ratio is a way of comparing whether the probability of a certain event is the same for different groups. 
TABLE 3 Retention and Recruitment of Older Workers (Logistic Regression Analysis)

\begin{tabular}{|c|c|c|c|c|}
\hline & \multicolumn{2}{|c|}{ Retention } & \multicolumn{2}{|c|}{ Recruitment } \\
\hline & Odds ratio & $z$-value & Odds ratio & $z$-value \\
\hline \multicolumn{5}{|l|}{ Trend effect } \\
\hline \multicolumn{5}{|l|}{ Year $(2000=$ reference category $)$} \\
\hline 2002 & $1.39^{*}$ & 1.99 & 0.81 & -1.45 \\
\hline 2005 & 1.28 & 1.09 & $0.29^{* *}$ & -4.31 \\
\hline 2008 & $3.18^{* *}$ & 6.81 & 1.30 & 1.63 \\
\hline 2009 & $2.10^{* *}$ & 4.66 & 0.79 & -1.56 \\
\hline \multicolumn{5}{|l|}{ Business-cycle effect } \\
\hline \multicolumn{5}{|l|}{$\begin{array}{l}\text { Size change (contraction }=\text { reference } \\
\text { category) }\end{array}$} \\
\hline Constant & 0.92 & -0.55 & 0.96 & -0.21 \\
\hline Growth & 1.26 & 1.56 & $1.59^{* *}$ & 2.94 \\
\hline \multicolumn{5}{|l|}{$\begin{array}{l}\text { Experienced shortages (no } \\
\quad \text { shortages }=\text { reference category) }\end{array}$} \\
\hline With some vacancies & $1.34^{*}$ & 2.28 & $2.33^{* *}$ & 5.76 \\
\hline With relatively many vacancies & $1.51^{* *}$ & 2.62 & $2.17^{* *}$ & 4.50 \\
\hline \multicolumn{5}{|l|}{ Human capital } \\
\hline \multicolumn{5}{|l|}{$\begin{array}{l}\text { Educational level (predominantly low } \\
\text { skilled = reference category) }\end{array}$} \\
\hline Predominantly medium-skilled & 1.31 & 1.68 & 1.04 & 0.25 \\
\hline Predominantly high-skilled & $1.74^{* *}$ & 3.02 & 1.37 & 1.71 \\
\hline Equally distributed & $1.46^{*}$ & 1.97 & 0.89 & -0.59 \\
\hline \multicolumn{5}{|l|}{ Control variables } \\
\hline Size of the organization (logarithm) & $1.10^{*}$ & 2.55 & $1.10^{*}$ & 2.36 \\
\hline \multicolumn{5}{|l|}{$\begin{array}{l}\text { Sector of industry (public } \\
\text { sector }=\text { reference category) }\end{array}$} \\
\hline Industry and construction & 1.21 & 1.16 & $1.65^{* *}$ & 2.91 \\
\hline Services & 1.30 & 1.87 & $1.43^{*}$ & 2.43 \\
\hline \multicolumn{5}{|l|}{$\begin{array}{l}\text { Share of workers older than } 50 \text { years } \\
\text { (none = reference category) }\end{array}$} \\
\hline $1 \%-9 \%$ of the workers older than 50 & 1.22 & 0.63 & 2.07 & 1.94 \\
\hline $10 \%-19 \%$ of the workers older than 50 & 1.34 & 0.96 & $2.91^{* *}$ & 2.87 \\
\hline $20 \%-29 \%$ of the workers older than 50 & 1.72 & 1.76 & $3.15^{* *}$ & 3.04 \\
\hline $\begin{array}{l}30 \% \text { or more of the workers older } \\
\text { than } 50\end{array}$ & $2.06^{*}$ & 2.32 & $3.86^{* *}$ & 3.53 \\
\hline Share female staff & 1.00 & 0.38 & $1.01^{* *}$ & 3.12 \\
\hline Age of respondent & 1.00 & -0.52 & 1.00 & -0.43 \\
\hline Gender of respondent & 0.87 & -1.22 & $0.69^{* *}$ & -3.22 \\
\hline Pseudo $R^{2}$ & \multicolumn{2}{|c|}{5.3} & \multicolumn{2}{|c|}{7.4} \\
\hline Log likelihood & \multicolumn{2}{|c|}{$-1,279.5$} & \multicolumn{2}{|c|}{$-1,232.8$} \\
\hline$\chi^{2}$ & \multicolumn{2}{|c|}{142.2} & \multicolumn{2}{|c|}{196.4} \\
\hline$N$ & \multicolumn{2}{|c|}{2,833} & \multicolumn{2}{|c|}{2,833} \\
\hline
\end{tabular}

Note. ${ }^{*}$ Significant at $p<.05 ;{ }^{* *}$ significant at $p<.01$.

Dependent variable: Do you encourage workers to remain employed until the age of 65 ? $(1=$ yes, $0=$ no). Dependent variable: Do you recruit older workers? $(1=$ yes, $0=$ no $)$.

With respect to retention of older workers, the results show that organizations with a predominantly highly skilled staff are more inclined to retain older workers. This is in line with what one would expect from our human-capital hypothesis (hypothesis: organizations that rely more heavily 
on high-skilled workers are more likely to recruit and retain older employees than organizations relying more on low-skilled workers). With respect to the recruitment of older workers, the human-capital hypothesis is not supported.

Furthermore, the findings show that personnel growth in the recent past positively affects efforts in recruiting older employees and that the degree of personnel shortages experienced positively influences retention and recruitment behaviors. In other words, the business-cycle hypothesis is supported for both recruitment and retention (bypothesis: labor shortages will increase the likelihood of recruitment or retention of older workers).

It is noteworthy that despite that the unemployment rate rose during the period from 2000 to 2005, the efforts to retain older workers were not negatively affected. In 2008, the results showed a significant increase in employers' behavior aimed at retaining older workers. In 2009, although the effect size was smaller than in 2008, employers were still more likely to retain older workers as compared to the year 2000. So, the data show a trend effect with employers being more supportive toward later retirement in their organizations. For recruitment, the results show that during the period from 2000 to 2005 , efforts to recruit older workers declined significantly. In 2008, when the external labor market contracted, the results show an increase in efforts made by employers to recruit older workers. In 2009, efforts to recruit older workers declined significantly again. Overall, recruitment behavior aimed at employing older workers seems to "breathe" in accordance with the economic climate, and there seems to be no clear trend effect, indicating that employers in the Netherlands are becoming more inclined to recruit older workers. The trend-effect hypothesis is thus only supported in case of the retention of older workers (bypothesis: over the time period from 2000 to 2009, employers increasingly recruited and retained older employees).

Besides, the results show that a higher share of workers older than 50 has a positive impact on employers' recruitment and retention of older workers. Finally, the results show that employers in "industry and construction" and in "services" are more inclined to recruit older workers than employers in the public sector.

\section{Relative Positions of Underrepresented Categories}

Employers may take different measures to deal with personnel shortages. In times when demand is high and the labor-supply pool is "drying up," employers will become more creative and diverse in their actions to fill vacancies (cf. Henkens et al., 2005). A number of target groups (women, older workers, non-native workers, and the disabled) are often identified as alternatives to the indigenous male labor force, which in many organizations traditionally constitutes the core of the workforce. From a job-search theoretical perspective (Phelps, 1970), employers associate each of these groups to a greater or lesser degree with higher labor or training costs-or lower 
expected benefits in terms of output-compared with the reference group of indigenous male workers. Based on these expectations, employers will rank members of different groups into a fictitious order of preference in the so-called "job queue" (Thurow, 1975).

Increasing labor shortages may be beneficial not only for older workers, but also for other less preferred groups in the labor market. The question, however, is whether older workers have benefited more than other groups or-on the contrary-less. So, what has happened to the relative position of older workers in the queue as compared to other underrepresented groups in the labor market? And what has happened to the relative position of older workers during the current recession?

Table 4 summarizes measures applied by employers to counteract personnel shortages by year. Enlisted are the most eminent underrepresented groups in the Dutch labor market: female workers, older workers, non-native workers, and disabled and partially disabled workers. The results show that the recruitment of female workers, older workers, and non-natives and the reintegration of disabled and partially disabled workers followed the labor market pattern: Between 2000 and 2005, we find a decrease in employers' willingness to hire these groups, while they became more attractive in 2008. The only exception to this pattern comes from the increase in employers' efforts in encouraging workers to continue working until age 65; this is the only dimension of employers' behavior not following the labor-market pattern and showing a substantial increase over the years 2000 to 2008. In 2009, all recruitment and retention of personnel plummeted. However, the relative position of older workers caught up: The retention of older workers in 2009 was the second most applied measure, and, although lower than in 2008, the retention is relatively high compared to the period 2000 to 2005 .

In relative terms, the results suggest that the position of older workers compared with those of female workers, disabled workers, partially disabled workers, and non-natives has improved over the last decade. However, older workers are still last in line when it comes to their recruitment.

TABLE 4 Measures Applied By Employers in Response to Personnel Shortages, 2000-2009 (\%)

\begin{tabular}{|c|c|c|c|c|c|}
\hline Measures & 2000 & 2002 & 2005 & 2008 & 2009 \\
\hline Recruiting more older workers & 20 & 15 & 6 & 28 & 17 \\
\hline $\begin{array}{l}\text { Encouraging workers to continue working } \\
\text { until the age of } 65\end{array}$ & 13 & 13 & 15 & 32 & 22 \\
\hline Recruiting more female workers & 55 & 38 & 23 & 41 & 31 \\
\hline Reintegrating (partially) disabled workers & 35 & 34 & 26 & 45 & 21 \\
\hline Recruiting more non-natives & $*$ & 33 & 23 & 43 & 21 \\
\hline
\end{tabular}

Note. *Data not available.

Source: Employers' surveys, 2000, 2002, 2005, 2008 and 2009. 
TABLE 5 Policies Applied by Employers in Order to Retain Older Personnel, 2000-2009 (\%)

\begin{tabular}{lrrrr}
\hline Measures & 2000 & 2005 & 2008 & 2009 \\
\hline Adjusting tasks/capabilities & & & & \\
$\quad$ Training programs for older workers & 20 & 14 & 21 & 16 \\
$\quad$ Demoting older workers to a lower rank and pay package & 7 & 6 & 17 & 10 \\
Work-leisure trade-off & & & & \\
$\quad$ Part-time early retirement & 35 & 39 & 46 & 42 \\
$\quad$ Possibilities of extra leave for older workers & 53 & 49 & 66 & 44 \\
$\quad$ Long-term career breaks (e.g., sabbatical leaves) & 8 & 8 & 15 & $*$ \\
Over-fatigue prevention & & & & \\
$\quad$ Decreasing the workload for older workers & 36 & 31 & 42 & 36 \\
$\quad$ Exemption from working overtime for older workers & 32 & 29 & 39 & $*$ \\
$\quad$ Working time adjustments & 45 & 28 & 38 & $*$ \\
$\quad$ Ergonomic measures & 57 & 50 & 66 & 44 \\
\hline
\end{tabular}

Note. Data not available for 2002 .

*Data not available.

Source: Employers' surveys, 2000, 2005, 2008, and 2009.

\section{Organizational Policies}

Organizations can apply different sets of policies in order to retain older personnel. In Table 5, policies are grouped into the following categories: measures to adjust tasks or capabilities, measures to balance work and leisure in a way more suitable to older workers, and measures aimed at preventing older workers from getting over-fatigued.

In 2009, 44\% of the employers applied ergonomic measures and extra leave opportunities for older workers. Least applied were measures to adjust tasks and capabilities. Measures in the area of over-fatigue prevention and work-leisure trade-off were applied two to three times more frequently than measures to adjust tasks and capabilities.

In the period 2000 to 2009, results show that organizational policies "breathed" simultaneously with the economic climate: a reduction of policies between 2000 and 2005, a revival in 2008, and a reduction in 2009 again. Part-time early retirement was the exception and showed a gradual increase during the period 2000 to 2008 and a small reduction in 2009.

Policies can be stimulating or permissive in nature. Overall, the higher levels of policies aimed at over-fatigue prevention and possibilities in the field of work-leisure trade-off suggest employers apply predominantly permissive policies regarding older workers. "Activating" measures, such as training programs for older workers, are considerably less sought after by employers.

\section{DISCUSSION AND CONCLUSIONS}

In this paper, we have addressed three main questions: Have employers' retention and recruitment behaviors toward older workers been 
changing over the last decade? Has there been a change in the relative position of older workers in the "job queue" as compared to other underrepresented groups in the labor market? And, have organizational policies regarding older workers been changing? To answer these questions we analyzed employers' recruitment and retention behaviors and compared organizational policies for the years 2000, 2002, 2005, 2008, and 2009 .

Both retention and recruitment behaviors of employers have been changing markedly over the last decade, though in different ways. Employers' retention behavior showed a clear and rather gradual time effect between 2000 and 2008: There was a significant increase in the number of employers encouraging workers to remain employed until age 65, even when changes in labor demand and experienced shortages were taken into account. During the recent recession, there has been a strong decline in efforts to retain older workers, but still the retention level is high when compared to the period 2000 to 2005.

When it comes to employers' recruitment behavior, we see a different picture. In the period 2000 to 2005, efforts to recruit older workers declined significantly, following the pattern of a rise in unemployment rates. In 2008, employers were more inclined to recruit older workers than they were in 2005, again following the development of unemployment rates. In 2009, employers' efforts to recruit older workers declined significantly again. Overall, recruitment behavior seems to change parallel to the economic climate. Despite the improvement of the relative position of older workers compared to other underrepresented groups in the Dutch labor marketfemale workers, non-native workers, and disabled and partially disables workers - there is no indication that employers are becoming more favorably disposed to recruit older workers.

Employers predominantly take permissive measures regarding older workers. Generic policy measures that seek to accommodate older workers, for example, offering them additional leave, are often perceived and put into practice as "age-conscious" personnel policies. The paradox of this type of age consciousness is that these actions seem in fact to limit the opportunities of the older worker in the Dutch labor market (Euwals, De Mooij, \& Van Vuuren, 2009). Employers are especially sceptical about the application of measures imposed by government or sector-wide labor agreements because these measures reduce older workers' employability and raise costs. Very few organizations have personnel policies targeted at narrowing the growing productivity-wage gap. So, although there is a growing tendency of employers to encourage older workers to continue working until age 65 , this behavior goes hand-in-hand with policies that imply a rather passive role for older workers.

The obstacles faced by older workers are not a typically Dutch phenomenon. These obstacles are found in many Western European countries, as shown in the OECD report Live Longer, Work Longer (2006). 
The Netherlands differs from other countries, however, because the labor costs of older employees are high and incumbent employees are relatively well-protected, which reduces their labor-market mobility. The paradoxical situation is that older workers occupy quite different positions in the Netherlands: The insiders hold a rather strong position, but outsiders-those who want to (re)enter the labor market-hold a weak position. This constitutes the crux of the policy dilemma that elaborate welfare states, especially in Europe, have to deal with. One aspect of employment protectionincome security and the seniority principle-stands in the way of the other aspect of protection-giving the unemployed reasonable chances at finding jobs.

This study has a number of limitations. One is its reliance on selfreported behavior. It is possible that respondents report recruiting or retaining older workers in accordance with dominant organizational or national policies but do not comply. Future studies may combine selfreported behavior with direct measures of hiring and retention behavior. Another limitation is that respondents are mainly recruited among "higher management," such as board members, managing directors, owners, plant managers, and heads of human resources. There may be a gap between what these higher managers think is happening in their organizations and what is actually happening in day-to-day business. On the one hand, one can argue that higher management is well-informed and has the best insight into the policies and organizational behavior. On the other hand, one can argue that higher management may have a limited view on practices in lower levels of the organization; people who are closer to the "real world" may provide other and maybe more reliable outcomes.

It remains to be seen whether the current economic recession obstructs the process of especially retaining older workers. The first pleadings to reestablish voluntary early retirement schemes have been already uttered in the Dutch media. The Dutch still carry their legacy of "the early exit culture," meaning that many employers share the opinion-and they are no exception to the large majority of Dutch people-that many older workers have "paid" their share and are entitled by now to a well-deserved period of rest and retirement. This inheritance of the early exit culture is also reflected in the fact that although the statutory retirement age is 65 , very few workers (fewer than 20\%) reach that age while still in the labor force. Employers contribute to this early exit culture: Many older workers would have worked longer if retirement had not been forced on them (Van Solinge \& Henkens, 2007). From this perspective, the intention of the Dutch Cabinet to raise the statutory age of retirement from 65 to 67 reflects high ambitions; Dutch employers and employees seem to be not even used to the idea of working till age 65. 


\section{REFERENCES}

Barth, M. C., McNaught, W., \& Rizzi, P. (1993). Corporations and the ageing workforce. In P. H. Mirvis (Ed.), Building the competitive workforce: Investing in buman capital for corporate success (pp. 156-200). New York: Wiley and Sons.

Brewster, C., Hegewisch, A., Mayne, L., \& Tregaskis, O. (1994). Methodology of the Price Waterhouse Cranfield Project. In C. Brewster \& A. Hegewisch (Eds.), Policy and practice in European buman resource management (pp. 230-245). London: Routledge.

Chiu, W. C. K., Chan, A. W., Snape, E., \&. Redman, T. (2001). Age stereotypes and discriminatory attitudes towards older workers: An East-West comparison. Human Relations, 54(5), 629-661.

DiMaggio, P. J., \& Powell, W. W. (1983). The iron cage revisited: Institutional isomorphism and collective rationality in organizational fields. American Sociological Review, 48, 147-160.

Equal Treatment Commission. (2007). Annual report 2007. Utrecht: Equal Treatment Commission.

European Commission. (2004). Increasing the employment of older workers and delaying the exit from the labor market. COM (2004) 146 final. Brussels: Author.

European Commission. (2005). Confronting demographic change: A new solidarity between the generations. Green paper. COM (2005) 94 final. Brussels: Author.

European Council. (2001). Presidency conclusions. Stockholm 23 and 24 March. Brussels: Author.

Eurostat. (1990). Statistical classification of economic activities in the European Community. NACE Rev. 1. Luxembourg: Eurostat.

Euwals, R., De Mooij, R., \& Van Vuuren, D. (2009). Rethinking retirement. The Hague: CPB Report.

Guillemard, A., Taylor, P., \& Walker, A. (1996). Managing an ageing workforce in Britain and France. Geneva Papers on Risk and Insurance-Issues and Practice, 21, 478-501.

Henkens, K. (2005). Stereotyping older workers and retirement: The managers' point of view. Canadian Journal on Aging, 24(4), 353-366.

Kalleberg, A. L., Knoke, D., Marsden, P., \& Spaeth, J. (1996). Organizations in America: Analyzing their structures and human resource practices. London: Sage.

Koppes, L. L. J., De Vroome, E. M. M., Mol, M. E. M., Janssen, B. J. M., \& Van den Bossche, S. N. J. (2009). Nationale Enquête Arbeidsomstandigheden 2008 ('National survey labor conditions, 2008'). Delft: TNO.

OECD. (2001). Ageing and income-Financial resources and retirement in 9 OECD Countries. Paris: OECD.

OECD. (2006). Live longer, work longer. Paris: OECD.

Phelps, E. S. (1970). Microeconomic foundations of employment and inflation theory. London: Macmillan.

SZW, Ministry of Social Affairs and Employment. (1991). Ouderenbeleid in arbeidsorganisaties. The Hague: Ministry of SZW/Loontechnische Dienst. 
Taylor, P., \& Walker, A. (1998). Employers and older workers: Attitudes and employment practices. Ageing and society, 18(6), 641-658.

Thurow, L. C. (1975). Generating inequality: Mechanisms of distribution in the U.S. New York: Basic Books.

Van Dalen, H., Henkens, K., \& Schippers, J. (2009). Dealing with an ageing labour force: What do European Employers expect and do? Journal of European Social Policy, 19(1), 47-60.

Van Dalen, H., Henkens, K. \& Schippers, J. (2010). How do employers cope with an ageing workforce? Views from employers and employees. Demographic Research, 22(32), 1015-1036.

van Imhoff, E., \& Henkens, K. (1998). The budgetary dilemmas of an aging workforce: A scenario analysis for the public sector in the Netherlands. European Journal of Population, 14(1), 39-59.

Van Solinge, H., \& Henkens, K. (2007). Involuntary retirement: The role of restrictive circumstances, timing and social embeddedness. Journal of Gerontology: Social Sciences, 62B(5), S295-S303.

Vickerstaff, S., Cox, J. \& Keen, L. (2003). Employers and the management of retirement. Social Policy \& Administration, 37, 271-287. 